\title{
Deference, expertise and information-gathering powers
}

\section{Cora Chan*}

This article explores two questions. First, in adjudicating claims under the Human Rights Act 1998, should the court defer to the executive or legislature on the ground that the latter two institutions possess superior expertise or information-gathering powers, when such expertise or powers fail to generate persuasive first-order reasons for the court? This article argues that rationality requires courts to defer on these second-order grounds of institutional capacity in situations of judicial uncertainty. Secondly, this article examines an underexplored question in the current literature: when is it justified for courts to consider the government as possessing second-order grounds of institutional capacity that warrant deference? It is argued that rational, impartial and open adjudication in the post-HRA era requires the government to prove its claims of superior institutional capacity, and courts to openly scrutinise such claims by considering a number of factors, including, crucially, the government institution's track record of expertise and credibility.

\section{INTRODUCTION}

The Human Rights Act 1998 ('HRA'), with its increased powers of judicial scrutiny, has ignited heated debates on judicial deference in the UK. The grounds of deference contested include institutional capacity, democratic legitimacy and prudential concerns. ${ }^{1}$ This article will focus on examining the debate on two aspects of the ground of institutional capacity: (1) expertise and (2) information-gathering powers. Deferring for these two factors seems the least controversial issue in the debate. Supporters of 'due deference' such as Murray Hunt, Aileen Kavanagh, Jeff King and Alison Young, argue that assigning weight to views generated by superior expertise and relevant information is a requirement of rationality and part of ordinary judicial function. ${ }^{2}$ Some even claim that the strongest opponent to deference

\footnotetext{
*Assistant Professor, Faculty of Law, University of Hong Kong. The author would like to thank Trevor Allan, Janice Brabyn, Tony Carty, Joseph Chan, Peter Chau, Richard Cullen, Helen Fenwick, Lusina Ho, Puja Kapai, Jacqueline Law, Mingchiu Li, Leticia Tang, Scott Veitch, Po Jen Yap, the two anonymous reviewers and participants at the Society of Legal Scholars Annual Conference 2011.

${ }^{1}$ Although there are overlapping considerations regarding these three grounds of deference, there are distinct concerns too and it is possible to discuss these grounds separately.

${ }^{2}$ M Hunt, 'Sovereignty's Blight: Why Public Law Needs "Due Deference" in N Bamforth and P Leyland (eds) Public Law in a Multi-Layered Constitution (Oxford: Hart Publishing, 2003) 337, pp 353-354; AL Young, 'In
} 
- TRS Allan - can side with them on this. ${ }^{3}$ Indeed in various places Allan seems to have conceded this point. ${ }^{4}$ So what is left for us to discuss?

This article will examine this apparently resolved debate by discussing two issues. First, in adjudicating claims under the HRA, should the court defer to the executive or legislature on the ground that these institutions possess superior expertise or information-gathering powers, when such expertise or powers fail to generate persuasive reasons for the court on the merits of the case? This, I argue, is the central issue that divides Allan and due deference supporters in the debate on deference on the ground of institutional capacity. Whilst both sides agree that courts should defer when expertise and information-gathering powers generate persuasive first-order reasons, they differ on whether courts should defer for these factors as second-order reasons, ie when such factors fail to produce convincing reasons on the legal merits. In particular, contrary to due deference supporters, Allan considers it illegitimate to defer on second-order grounds in any situation because courts should only enforce their own balance of first-order reasons. This article will put forward a case against Allan on this contentious issue. Assuming that second-order grounds of institutional competence are established, rationality calls for deference thereon at least in the limited situation where courts are uncertain what the legal answer is.

Secondly, this article will explore when it is justified for courts to consider the government as possessing second-order expertise and information-gathering powers that warrant deference in HRA cases. This is an important question that is underexplored in the current literature. Institutional superiority is not always self-evident. The practical implications and hence the justifiability of any theory of deference on second-order grounds would only be apparent if the theory contains an account of when such grounds can be taken to have been established. As I will later on explain, some prevalent accounts of deference, whilst making the right start in acknowledging that deference on second-order grounds is sometimes called for, are ultimately unjustified due to their flawed approach to establishing such grounds. Further, recent blunders in governance, including not least the intelligence

Defence of Due Deference' (2009) 72(4) MLR 554 at 555, 570; A Kavanagh, 'Defending Deference in Public Law and Constitutional Theory' (2010) 126 LQR 236 at 244-245.

${ }^{3}$ Young, ibid, at 574; Kavanagh, ibid, at 243-244, 249-250. Jowell supports in principle deference on the ground of institutional competence. J Jowell, 'Judicial Deference and Human Rights: a Question of Competence' in P Craig and R Rawlings (eds), Law and Administration in Europe: Essays in Honour of Carol Harlow (Oxford: OUP, 2003) p 67; J Jowell, 'Judicial Deference: Servility, Civility or Institutional Capacity?' (2003) PL 592.

${ }^{4}$ As will be explained in section 1, Allan endorsed this point only in relation to deference on first-order grounds, but not that on second-order grounds. TRS Allan, "Human Rights and Judicial Review: A Critique of "Due Deference"' (2006) 65 CLJ 671 at 672, 676; TRS Allan, 'Judicial Deference and Judicial Review: Legal Doctrine and Legal Theory’ (2011) 127 LQR 96 at 97, 103, 105. 
failure over Iraq, give us reasons to question traditional presumptions about government expertise and credibility. ${ }^{5}$ It is particularly important in this day and age to ask when it is legitimate for courts to consider government institutions as experts and rely uncritically on the latter's judgments.

Unfortunately, none of the scholars supporting deference on second-order grounds of institutional capacity have systematically addressed when such grounds can be taken to have been established. This article will attempt to sketch an answer to this question, taking into account the requirements of rational, fair and open adjudication in the post-HRA era. I argue that the burden of proving claims of superior institutional capacity rests with the government, and the court must openly scrutinise such claims by considering a number of factors, including, crucially, the government institution's track record of expertise and credibility.

This article will adopt the definition of 'deference' given by due deference supporters, namely, the assigning of varying degrees of weight to an institution's views. 'Government' will be used in this article to refer to the executive or legislature.

In the following, I will first expound the distinction between deference for first-order as opposed to second-order reasons. I will then explain why deference for second-order reasons is sometimes justified. Next, I will suggest factors which courts should consider in evaluating whether the government possesses second-order institutional competence, and the burden of proof and manner of scrutiny that ought to be adopted. Following from this, I will address some potential objections on feasibility against my proposals. Finally, I will conclude with some observations on the current debate on due deference.

\section{UNCOVERING THE BATTLELINE: DEFERENCE ON SECOND-ORDER GROUNDS}

This article deploys the distinction between first-order, substantive reasons and second-order, institutional reasons. ${ }^{7}$ The former relate to the legal merits of the particular case in question, based on which the court makes its own determination of rights. The latter are concerns of institutional competence, democratic legitimacy and prudence, which do not affect the court's

\footnotetext{
5 Feldman convincingly challenged presumptions about politicians' superior institutional competence in assessing terrorism-related risks in 'Human Rights, Terrorism and Risk: the Roles of Politicians and Judges' (2006) PL 364 at 377-384. See also T Poole, "Courts and Conditions of Uncertainty in "Times of Crisis"” (2008) PL 234 at 244-258; C Walker, 'The Threat of Terrorism and the Fate of Control Orders' [2010] PL 3 at 15; below n 95-100.

${ }^{6}$ Kavanagh, above n 2, at 223, 233; Young, above n 2, at 555; Hunt, above $n 2$.

${ }^{7}$ Kavanagh, above n 2, at 230; S Perry, 'Second-order Reasons, Uncertainty and Legal Theory' 62 S Cal L Rev 913 (1988-89); J Raz, Practical Reasons and Norms (London: Hutchison, 1975) ch.1.
} 
own substantive determination of the legal merits. Following due deference theorists, this article will treat second-order reasons as 'reweighting reasons' ${ }^{8}$ If a court defers to the government on second-order grounds, it will be treating the government's case as stronger than what the court, on its own balance of first-order reasons, considers it to be. ${ }^{9}$

Building on this distinction, I would like to highlight an overlooked point in the current literature - a point that will illuminate what unites and sets apart the two camps in the debate on due deference, namely that the government's expertise and intelligence-gathering powers can figure in the court's reasoning process as first- or second-order reasons. Let us look at the government's information-gathering powers first, before turning to consider expertise. If the government is able to demonstrate its superior information-gathering ability by disclosing the relevant information to the court, and the court is persuaded by such information on the legal merits, then the government's information-gathering powers would be factored into the court's first-order reasoning. Yet if the government is unable to disclose to the court (not even on a confidential basis) the information which it claims can ground its conclusions, ${ }^{10}$ its information-gathering powers will be unable to generate persuasive reasons on the substantive merits. If the court nevertheless gives weight to the conclusions that are founded upon the undisclosed information, then the government's information-gathering powers would figure in the court's reasoning as a second-order reason.

As for the government's expertise, if it generates convincing reasons for the court on the legal merits of the particular case in question, then it will be relevant as a first-order reason. The government's expertise will be 'subsumed within' the court's first-order analysis. ${ }^{11}$ However, if the expertise fails to generate such convincing reasons but is nevertheless given weight by the court, then it will be relevant as a second-order reason. Claims of second-order expertise usually take the form of the government, generally, having expertise in deciding the type of issue in question. The claim is that even if the government cannot demonstrate that it is correct on the merits of this particular case, the fact that it was usually correct in the past in deciding this type of issues is a reason that warrants deference this time. This distinction

\footnotetext{
${ }^{8}$ As opposed to exclusionary reasons, above n 6. Perry, ibid, at 932; cf J Raz, The Morality of Freedom (Oxford: Clarendon Press, 1988) ch 3; P Soper, The Ethics of Deference (Cambridge: CUP, 2002) pp 38-47; D Dyzenhaus, 'The Politics of Deference: Judicial Review and Democracy' in M Taggart (ed) The Province of Administrative Law (Oxford: Hart Publishing, 1997) p 286.

${ }^{9}$ Perry, above $\mathrm{n} 7$, at 932; Kavanagh, above $\mathrm{n} 2$, at 233.

10 The kind of situation described here should be distinguished from two other circumstances: (1) where information is hidden from the litigant but not the court, as in what happens when the closed material procedure is used; (2) where the government conceals information under public interest immunity and does not seek to rely on such information in the trial. The latter two situations are not the subject of this article's concern.

${ }^{11}$ Allan, above n 4 LQR, at 99-100.
} 
between first- and second-order reasons is thrown into relief by two House of Lords decisions. In $\operatorname{Re} E$ (a child), ${ }^{12}$ in deciding whether the police has discharged its positive obligations under art 3 of the European Convention on Human Rights in protecting the claimant's child from loyalist violence that broke out on the child's path to school, the majority's reasoning displayed an example of deference for first-order reasons of expertise. Lord Carswell argued that weight should be assigned to the police's views on how to deal with the riot since the police's expertise generated persuasive reasons on the legal merits of this particular case. ${ }^{13}$ The police offered evidence to show that clearance of the group using conventional crowd tactics had been tried but backfired. The police also argued that arrest by force had been hindered by the landscape of the surroundings. In the end the court was persuaded by the police's view that a negotiated settlement was necessary in the circumstances. ${ }^{14}$ The government's experience generated persuasive reasons that swayed the court's own substantive reasoning.

In contrast, the House of Lords' reasoning in the first part of the Belmarsh judgment exhibited an example of deference on second-order grounds of expertise. ${ }^{15}$ On the question of whether there was a 'public emergency threatening the life of the nation' that justified the government's derogation from the bar against indefinite detention, the majority deferred to the decision of the executive, partly because it believed that the executive generally possessed more expertise in making political judgments, national security decisions and predictions of human behaviour. ${ }^{16}$ The alleged general expertise did not translate into persuasive reasons for the court on the legal merits of this specific case, in particular, for the late Lord Bingham, who had 'misgiving' about, and Lord Scott, who had 'very great doubt', whether such emergency existed in the circumstances. ${ }^{17}$ Indeed it seems that the majority's own balance of reasons would not have found the requisite level of emergency. Considerations of the executive's general expertise in making national security judgments added extra weight to the government's case, and functioned in the majority's calculation as a second-order reason.

It is uncontroversial that the government's expertise and intelligence-gathering powers should attract weight if they can generate convincing first-order reasons. Supporters of due

\footnotetext{
${ }^{12} \operatorname{Re} E$ (a child) [2008] UKHL 66.

${ }^{13}$ Ibid at [55-59].

${ }^{14}$ Ibid.

${ }^{15}$ A v Secretary of State for the Home Department [2005] 2 A.C. 68 ('Belmarsh').

${ }^{16}$ Ibid at [26, 29, 116, 154, 166, 226].

${ }^{17}$ Belmarsh, at [26, 154].
} 
deference and Allan agree on this. ${ }^{18}$ This unison accounts for the apparent harmony between the two camps and the alleged 'concessions' that Allan made on the issue of deference. ${ }^{19}$

The real contention between Allan and due deference supporters lies in whether judges should give weight to official expertise and information-gathering powers that fail to generate convincing first-order reasons. Perhaps with the exception of Hunt who is more ambiguous on this issue, ${ }^{20}$ the due deference camp clearly accepts that such deference is sometimes warranted. Kavanagh makes this argument most explicitly. According to her, courts have a duty to balance substantive reasons against institutional ones. The two levels of reasoning are 'conceptually separate': questions of institutional capacity cannot be answered by substantive arguments about the legal merits. ${ }^{21}$ Kavanagh, King and Young all envisage situations of judicial uncertainty, where the government's expertise fails to tilt the court's balance of firstorder reasons in favour of the government, but where, they argue, the court should nonetheless give weight to such expertise. ${ }^{22}$

In contrast, Allan objects to deference for reasons that are extraneous to the court's firstorder reasoning. The court should take into account superior competence only insofar as it is demonstrated by convincing arguments or evidence tailored to the circumstances of the case. A bad argument for breaching rights will not be strengthened by the fact that it is made by a well-informed institution. ${ }^{23}$

\section{RATIONALITY AND DEFERENCE ON SECOND-ORDER GROUNDS}

The dispute between the two camps stems from their fundamentally different starting premises. Allan's premise is that courts should always only act on their own balance of firstorder reasons. If they defer on second-order grounds, they would abdicate judicial responsibility and impartiality and inhibit the growth of a culture of justification. Since deference theories ask courts to act for second-order reasons, Allan concludes that these

\footnotetext{
${ }^{18}$ Hunt, above n 2, p 340; Young, above n 2, at 575; A Kavanagh, Constitutional Review under the UK Human Rights Act (Cambridge: CUP, 2009) pp 187-189; Allan, above n 4 CLJ, at 689; Allan, above n 4 LQR, at 106; TRS Allan, 'Deference, Defiance, and Doctrine: Defining the Limits of Judicial Review' (2010) 60 U of Toronto LJ 41-59, at 48.

${ }^{19}$ Young, above n 2, at 574-575; Kavanagh, above n 2, at 243-244, 249-250; Allan, above n 4 LQR, at 96, 97, 103, 105; Allan, above n 4 CLJ, at 672, 676.

${ }^{20}$ The cases that Hunt cited as displaying due deference all seemed to be illustrations of deference to expertise as first-order reason. Hunt, above $\mathrm{n} 2$.

${ }^{21}$ Kavanagh, above n 2, at 231, 232, 250; A Kavanagh, 'Judicial Restraint in the Pursuit of Justice' (2010) 60 U of Toronto LJ 23 at 31-32.

${ }^{22}$ Kavanagh, above n 2, at 233-235; J King, 'Institutional Approaches to Judicial Restraint' (2008) 28(3) OJLS 409, at 438-9; Young, above $\mathrm{n}$ 2, at 566, 570, 573.

${ }^{23}$ Allan, above n 4 CLJ, at 688-689; Allan, above n 18, at 51.
} 
theories call for such abdication and inhibition. ${ }^{24}$ On the other hand, the starting premise of due deference supporters is that courts should sometimes defer on second-order grounds.

I argue that Allan's premise is untenable. Assuming that second-order reasons of expertise and intelligence-gathering powers are validly established, ${ }^{25}$ deference for such reasons is justified at least in the limited situation where the court is uncertain which side's arguments are more convincing. This occurs when the court's own balance of first-order reasons is (1) even (when arguments for and against finding an unjustified rights violation, or a related specific factual or normative assessment, are finely balanced to the court) or (2) unclear (where due to epistemic limitations the court is unsure of the weight of one or both sides' arguments). ${ }^{26}$ Although Allan disagrees with some due deference supporters in insisting that there is in principle one right answer in every legal case, ${ }^{27}$ he in fact envisages such situations of uncertainty as he accepts that there may be reasonable epistemic disagreements over what the correct answer may be. ${ }^{28}$

In these situations of judicial uncertainty, rationality requires the court to defer to the institution whose subjective balance of first-order reasons is more likely to be correct, ie more likely to resemble the objective balance of first-order reasons. ${ }^{29}$ If the government is able to establish that it has better expertise than the court in deciding the type of issue in question, or that it has more information than the court does to decide the issue, there are reasons to believe that the government is more likely than the court to get it right, and the obvious course for the court would be to defer. ${ }^{30}$ Deference to an institution that possesses superior expertise or knowledge is, as Kavanagh emphasises, 'a rational response to [judicial] uncertainty'. 31

An analogy can be drawn with courts' treatment of conflicting expert opinion. The case law confirms that while courts choose among competing opinions primarily according to the

\footnotetext{
${ }^{24}$ Allan, above n 18, at 42; Allan, above n 4 LQR, at 100, 101, 109; Allan, above n 4 CLJ, at 688.

${ }^{25}$ Sections 3 will explain when courts can consider such reasons as being established. My arguments also assume that the government body and the court are dealing with the same question, an issue raised in B Foley, Deference and the Presumption of Constitutionality (Dublin: Institute of Public Administration, 2008) p 278.

${ }^{26}$ Judges have acknowledged that rights cases before them are finely contested. For recent judgments, see Quila $v$ Secretary of State for the Home Department [2010] EWCA Civ 148, at [52-62]; Regina (Mohamed) $v$ Secretary of State for Foreign and Commonwealth Affairs No. 2 (Guardian News and Media Ltd and ors intervening) [2011] QB 218, at [290]; Regina (Ghai) v Newcastle City Council (Ramgharia Gurdwara, Hitchin and others intervening) [2010] 3 WLR 737, at [121-123].

${ }^{27}$ King, above n 22, at 413, 425-426; Young, above n 2, at 576.

${ }^{28}$ Allan, above $\mathrm{n} 4 \mathrm{LQR}$, at 102 . For the distinction between indeterminacy and uncertainty, see $\mathrm{S}$ Besson, The Morality of Conflict (Oxford: Hart Publishing, 2005) pp 53-39.

${ }^{29}$ Perry, above $\mathrm{n} 7$, at 929.

${ }^{30}$ A similar point was made in T Hickman, Public Law after the Human Rights Act (Oxford: Hart Publishing, 2010) p 142.

${ }^{31}$ Kavanagh, above n 18, pp 171-172.
} 
cogency of their reasons, the 'impressiveness of an expert's qualifications and experience' are 'always relevant' in the courts' evaluation, and may attract extra weight that determines the outcome. ${ }^{32}$ This is highly intuitive, as an expert's qualifications and past experience are relevant to the likelihood of him being correct in the instant case. If two competing expert opinions seem equally cogent to the court, or, if the court is uncertain about the weight of one or both opinions, then the fact that one is given by a highly distinguished expert and the other by a less well qualified and experienced expert should logically act, respectively, as a tiebreaker or pointer.

In the landmark case on medical negligence, Bolitho, ${ }^{33}$ the House of Lords had to decide whether the defendant doctors had been negligent in failing to intubate a child. There was competing and comparably strong medical evidence on what should have been done. The court ultimately found for the defendants, and it was clear that the court attached much weight to the impressive qualifications of the main expert witness for the defendants, whom the court called 'a most distinguished expert'. ${ }^{34}$ Similarly, in a recent case on competing expert evidence, Keran Louise Henderson, ${ }^{35}$ the Court of Appeal, in deciding which competing expert opinion to rely on in a suspected case of child abuse, discounted the weight attached to the evidence of one expert since 'his experience was more historic... he has not conducted autopsies... for many years...,36

Analogically, in constitutional rights review, if courts are uncertain what the balance of first-order reasons requires, and some additional factor suggests that the government is more likely to be correct, no rational court should resist deference to the government.

One interpretative point before we move on to consider Allan's objections to deference. Some may interpret Allan's theory as being able to accommodate the proposed deference to second-order expertise and intelligence. This reading is buttressed by Allan's acknowledgment that judicial uncertainty can affect the degree of permissible discretion: 'The court will obtain its sense of the limits of permissible interference from the degree of confidence about the most appropriate response that their study of the competing claims permits them to acquire. ${ }^{37}$ I contend that Allan is simply reinforcing the point that ordinary

\footnotetext{
${ }^{32}$ For recent cases, see Hassan Masood v Aileen Kerr \& ors [2010] EWCA Civ 1347; Leicestershire County Council $v W \& P$ [2002] EWCA Civ 710. T Hodgkinson and M James, Expert Evidence: Law and Practice (London: Sweet \& Maxwell, $3^{\text {rd }}$ edn, 2010) pp 386-390; Lord Woolf, 'Are the Courts Excessively Deferential to the Medical Profession?’ (2001) 9 Medical Law Review 1, at 10-11.

${ }^{33}$ Bolitho $v$ City and Hackney Health Authority [1997] 3 WLR 1151.

${ }^{34}$ Ibid at [244].

${ }^{35}$ Keran Louise Henderson v The Crown [2010] EWCA Crim 1269.

${ }^{36}$ Ibid at [61].

${ }^{37}$ Allan, above n $4 \mathrm{LQR}$, at 111.
} 
judicial analysis of particular claims of rights can allow different margins of discretion to the government, and that there is no need for a separate doctrine of deference. This and other similar statements of his cannot be read as permitting deference on grounds that fail to produce convincing first-order reasons, as this would fly in the face of (1) his repeated emphasis that the court should only bow to expertise insofar as it generates persuasive reasons for curtailing rights in the particular case ${ }^{38}$ and (2) his insistence that there should not be principles of deference 'operating independently' from detailed, contextual analysis of 'specific claims of right... in accordance with their intrinsic merits. ${ }^{39}$ Any attempt to defend Allan's theory as being receptive to the proposed deference on second-order grounds would have to be squared with these unequivocal remarks.

Allan raises three main objections against deference on second-order grounds. First, he argues that if the court defers for second-order reasons, it would abdicate its duty to enforce its 'own best judgment of a party's legal rights'. ${ }^{40}$ The court violates the rights that it is supposed to enforce by allowing extraneous considerations to displace its own appraisal of substantive reasons. ${ }^{41}$ My reply is, it may be true that the court's primary duty is to enforce its own determination of legal rights. However, in cases where the court's subjective balance of first-order reasons fails to return an answer, the court's best judgment can only be made on the basis of other reasons that suggest which institution is more likely to produce correct answers. Second-order reasons of expertise or information-gathering powers assist courts in finding out, rather than compel them to set aside, the right answer. ${ }^{42}$ If the court turns a blind eye to the superior expertise of the government or to information which the government is in a unique position to possess, it runs the risk of enforcing the 'wrong rights'. ${ }^{43}$

Allan's second objection is that deference for second-order reasons calls for an abandonment of judicial impartiality. ${ }^{44}$ Whatever logic deference may yield in other contexts, it has no role to play in adjudication, which should proceed on the basis of reasons applicable to the case in question. ${ }^{45}$ Denying a claimant its rights merely 'in virtue of his comparative ignorance or lack of special qualifications' goes against 'adjudication as an institutional expression of the influence of reasoned argument in human affairs'. ${ }^{46}$ Allowing the

\footnotetext{
${ }^{38}$ Allan, above n 4 CLJ, at 676, 683, 689; above n 4 LQR, at 107.

${ }^{39}$ Allan, above n 4 CLJ, at 672, 674, 675, emphasis added.

${ }^{40}$ Allan, above n 4 LQR, at 101; above n 4 CLJ, at 688.

${ }^{41}$ Allan, above n 4 LQR, at 100, 109.

${ }^{42}$ See T Hickman, 'The Substance and Structure of Proportionality' (2008) PL 694 at 697.

${ }^{43}$ Young, above $\mathrm{n} 2$, at 576.

${ }^{44}$ Allan, above $\mathrm{n} 4 \mathrm{CLJ}$, at 676.

${ }^{45}$ Ibid at 692-693.

${ }^{46}$ Ibid at 693 .
} 
government to more easily discharge its burden of proof on the basis of factors that are extraneous to the legal merits gives the government an unfair advantage. Unfairness is aggravated by the fact that the litigant will have no opportunity to challenge extraneous expertise or information that is not demonstrated by argument. ${ }^{47}$

This relates to Allan's third objection, that deference is inimical to the development of a 'legal culture of justification'. ${ }^{48}$ If the government is able to get by with general claims of expertise and information-gathering powers that are unable to specifically justify its conclusions in the particular case, then the court is granting the government's conclusions without requiring them to be fully justified.

These arguments seem powerful, but are misguided. It is not clear why the government's burden of proof can only be discharged with reasons and evidence that directly apply to the case, and the government's general expertise and exclusive access to information can never assist in tipping the balance of proof. If the court is unsure which viewpoint is more persuasive, and the government can demonstrate its track record of getting it right in this type of cases and its credibility regarding claims of useful secret intelligence information, then such established institutional competence should logically add strength to the government's case. Such deference does not corrupt the reasoned nature of adjudication: institutional competence itself needs to be established by reasons and evidence, and giving weight to established institutional competence aids the court to pick the right reasons to rely on. The litigant is free to challenge the government's evidence of expertise and credibility. The court is not being partial, nor is the government's conclusion allowed to stand without justification, since the form of deference proposed here requires the government to fully prove that it possesses institutional advantages that render it more likely to reach the right answer in the present case.

\section{ESTABLISHING SECOND-ORDER REASONS}

So far I have argued that courts, in adjudicating claims under the HRA, should defer on second-order institutional grounds in situations of judicial uncertainty, if such grounds are established. The crucial question then becomes, when is it justified for courts to consider such grounds as having been established? The question is no longer whether courts should defer to a government body that is more likely to be correct. Rather, it is under what circumstances

\footnotetext{
${ }^{47}$ Ibid at 692

${ }^{48}$ Ibid at 694.
} 
courts can legitimately consider a government institution as being more likely to be correct, where the latter fails to tilt the former's balance of first-order reasons.

In the following, I will outline an answer to this underexplored question based on the imperatives of rational, impartial and transparent adjudication in the post-HRA landscape. I will build on an insight of Poole that has not yet been fully explored. In an important article, Poole argues that in terrorism cases involving risks and secrecy, public reason requires courts to challenge the evidential basis of the government's assessments. ${ }^{49}$ Courts should not merely embrace, sidestep or ignore risks; instead, they must try to gain access to as much information as possible and find ways of testing it. ${ }^{50}$

I will elaborate on why courts should adopt this probing attitude to test the government's claims of second-order institutional competence, and how such probing should be undertaken. I do not seek to propose a universal, timeless formula for assessing institutional competence - which is neither desirable nor possible, since what it takes to establish institutional capacity varies on a case-by-case basis, across subject areas ${ }^{51}$ and with the nature of the question involved. ${ }^{52}$ What I will do, instead, is to suggest factors which courts must consider in deciding whether they can rely on a government's judgment, the circumstances that may affect the weight of these factors, and the burden of proof and manner of scrutiny that should be adopted. As will be seen, although I accept that deference on second-order grounds of expertise and information-gathering powers is sometimes called for, the rules of adjudication under the HRA demand a high threshold to be crossed before such grounds can be taken to have been founded.

\section{(a) Burden of proof and manner of scrutiny}

Under the HRA, the government bears the burden of proving the proportionality of any prima facie infringement of rights. This reflects the value we attach to rights: any encroachment must only be made to the extent necessary, and the government must fully justify any infringement. The logic that follows is, if at the justification stage the government wishes to claim that it possesses second-order grounds of institutional competence that deserve

\footnotetext{
${ }^{49}$ Poole, above $n$ 5, at 253-259.

${ }^{50}$ Ibid at 248-258.

${ }^{51}$ Although most cases discussed in this article are concerned with national security (since second-order reasons are most prominently relied on by the government in this context), my arguments are intended to apply to HRA cases of all subject matters.

${ }^{52} \mathrm{Eg}$ whether it is a determination of facts, risk assessment or moral judgment.
} 
deference - eg useful information that cannot be revealed to the court, and/or general expertise in the subject area - then it must prove that this is the case.

If courts work from what Poole calls a 'presumption of good faith', ${ }^{53}$ granting claims of superior expertise and information-gathering powers without requiring them to be fully proved, they would distort the game: they would lighten the government's burden of proof, giving it an unfair advantage. Moreover, presumptions of good faith jettison the 'sceptical habit of mind that should always underpin... judicial review'. ${ }^{54}$ Judicial fairness and the culture of justification require the government to adduce evidence to prove its claims of institutional capacity.

If the government fails to tilt the court's first-order balance (resulting in judicial uncertainty) and further fails to prove second-order grounds for deference, then it would have to lose since it has not discharged its burden of proof; it has failed to 'earn' deference. ${ }^{55}$

Of course, that the government fails to show that it has superior institutional abilities does not entail that the court is in any better position than the government to determine the issue; the court may be as incapable of making the decision. Yet this is no reason for deference. The burden is on the government to convince the court that it is rights-compliant. The court need not show that it has superior institutional competence before ruling against the government. Where the latter fails to convince the court on both first- and second- order levels, the court ought to rule against it on the basis that it has failed to discharge its onus. ${ }^{56}$

As explained in section 2, the court should consider the government's second-order claims of superior institutional abilities in situations of judicial uncertainty. Here impartiality and open justice would require courts to openly scrutinise the evidence supporting these claims, and to explain to the litigant why such second-order claims for deference have or have not been granted, eg what makes the court believe that the institution indeed possesses general expertise in this area, or the said secret intelligence? Otherwise, the litigant would have no opportunity to challenge the court's decision to defer - a decision which would most likely have accounted for why the litigant has lost. As Poole contends, the duty of candour requires courts to openly confront and not just cast doubt on ('sidestep') unreliable risk

\footnotetext{
${ }^{53}$ Poole, above n 5, at 249.

${ }^{54}$ Ibid at 250 .

${ }^{55}$ This expression was coined by Hunt, above n 2, p 340.

56 Thus Komesar's general account of relative institutional competence, while helpful, cannot be nakedly transposed to the debate on deference under the HRA, since it omits to consider the burden of proof in rights adjudication. NK Komesar, Imperfect Alternatives: Choosing Institutions in Law, Economics, and Public Policy (Chicago: University of Chicago Press, 1996).
} 
assessments. ${ }^{57}$ If open justice requires the court to openly evaluate the parties' first-order arguments and to explain its conclusions thereon, it would similarly require the court to expressly scrutinise the evidence supporting second-order claims of institutional capacity and to fully explain why deference therefor has or has not been granted.

\section{(b) Factors for courts to consider}

The basic idea of rational decision-making is that conclusions must be grounded in reason and not blind faith. Where the government alleges that it possesses useful secret information or general expertise on a subject, it would only be rational for courts to grant these claims if there are reasons to show that they are true. Since second-order grounds of expertise and information-gathering powers cannot persuade the court on the legal merits, they are by nature unsupported by concrete reasons applicable to the case. Courts should therefore consider relevant factors extrinsic to the case in assessing whether to trust that the alleged expertise or information exists. It is ultimately for the courts to weigh up these factors. The overarching test must always be: taking into consideration all relevant factors, is the government's claim of useful secret information or superior expertise in the subject area worthy of trust? Deference theorists have suggested the following factors for courts to consider: ${ }^{58}$

1. Whether the institution possesses features (eg procedures, powers, resources, systems of accountability) that would facilitate its arriving at right answers.

2. The nature and extent of scrutiny by the institution of the decision in question.

These are indisputably relevant factors. However, a crucial omission from the list is the institution's past record of expertise and credibility. ${ }^{59}$ This refers to past incidents that demonstrate the institution's ability to make the type of judgments in question and its integrity in claiming possession of useful information that cannot be revealed.

Rationality requires a court to consider a government institution's past performance and credibility when determining whether the institution indeed possesses the alleged useful

\footnotetext{
${ }^{57}$ Poole, above $n$ 5, at 250-251.

${ }^{58}$ See eg Hunt, above n 2, p 353; Kavanagh, above n 18 at 182-190; Young, above n 2, at 565-567; King, above $\mathrm{n}$ 22. See also Jowell in Craig and Rawlings (eds), above n 3, p 80; J Raz, 'Disagreement in Politics' 43 Am J Juris 25 (1998) at 45-46; L Fuller and K Winston, 'The Forms and Limits of Adjudication' 92(2) Harvard Law Review 353 (1978); Komesar, above n 56.

${ }^{59}$ Komesar alluded that history may be important for assessing institutional competence. Yet this factor seems to have played a small role in his theory. Komesar, above n 56, p 259.
} 
secret information or general expertise. Let us examine expertise first. Whilst institutional features are relevant to establishing general expertise in making particular kinds of judgments, track records of performance are equally, if not more, important, and cannot be ignored. What combination of institutional features would more likely render correct outcomes in a particular time and place cannot be determined in the abstract and must be tested by experience. Courts need to consider whether the institution had in the past made correct judgments in the area concerned, in order to ascertain if its institutional features in fact make it more likely to arrive at right answers. For instance, the Security Service certainly possesses the institutional feature of being staffed by people who are experienced in analysing intelligence. However, whether these people will properly make use of their powers and responsibly learn from experience in light of the institution's current accountability mechanisms can only be confirmed by track records. ${ }^{60}$ That past performance is needed to verify if an institution is functioning adequately is particularly true in the context of national security, because defence strategies become out-dated quickly. ${ }^{61}$ It was explicitly admitted by the former head of the Security Service that the organisation must earn public trust from track records. ${ }^{62}$

If a court ascertains expertise solely by looking at institutional designs without considering whether they worked, it would be relying on mere presumptions about the link between the possession of certain institutional designs and the ability to generate right answers, without testing whether such presumptions are in fact valid in the circumstances. This is equivalent to drawing conclusions from hypotheses without conducting experiments in scientific research.

Looking at an institution's past performance to ascertain if it is an expert is extremely intuitive once we revisit the analogy with expert opinion. Courts assess the professional expertise of doctors by examining their past performance, qualifications and reputation. If a doctor had repeatedly committed medical blunders in the field, say, misdiagnosed patients, or suffers from a bad reputation for publishing flawed findings in the field, courts would

\footnotetext{
${ }^{60}$ Various commentators have argued that the government has vested interests in playing up national security risks. See eg F de Londras, Detention in the 'War on Terror': Can Human Rights Fight Back? (Cambridge: CUP, 2011) chs 1, 3.

${ }^{61}$ The Coalition government recently accused the Blair government of not adapting our defence institutions to suit new circumstances. 'A Strong Britain in an Age of Uncertainty: the National Security Strategy' (Foreword) and 'Securing Britain in an Age of Uncertainty: The Strategic Defence and Security Review' (Foreword), both presented to Parliament in October 2010, available at http://www.official-documents.gov.uk/.

62 Transcript of the James Smart Lecture by the former Director General of the Security Service, Eliza Manningham-Buller, City of London Police Headquarters, 16 October 2003, p 4, available at https://www.mi5.gov.uk.
} 
(rightly, in my opinion) doubt if he really is an expert in the area and would choose to trust more reliable expert witnesses. There is no reason why government institutions should be exempt from this rational process of locating expertise, especially when something as important as potential violations of rights is at stake. As with dealing with other experts, courts ought to confirm if government institutions are experts on a certain matter by considering whether they had made correct decisions. ${ }^{63}$

I now move on to examine information-gathering powers. A court ought to consider an institution's past credibility in deciding whether to trust the latter's conclusions made based on concealed evidence. The court should consider the institution's credibility in two senses: (1) the competence sense: whether the institution's sources of information and assessments made based on that information had been reliable in the past, and (2) the good faith sense: whether the institution had been honest in claiming possession of useful information that could not be disclosed. Also, courts must consider if there is indeed a compelling need to conceal information from them. ${ }^{64}$ If the government body's sources of intelligence had been unreliable, or if it had repeatedly lied about its intelligence or exaggerated risks, it would not be rational for courts to trust it this time - the simple tale of the boy who cried wolf. If the court relies on conclusions made based on unrevealed evidence without considering the government institution's record of trustworthiness, it would be trusting the government's mere assertions that it possessed certain useful information.

Mere presumptions or assertions about superior institutional competence may turn out to be false. This partly explains why academics have unanimously rejected the 'spatial' approach to deference, whereby courts carve out certain subject matters that would automatically attract deference (eg national security) and others that do not (eg fundamental rights). ${ }^{65}$ This approach is problematic, partly because presumptions about the government's

\footnotetext{
${ }^{63}$ It may be objected that the analogy with expert opinion is flawed. In situations of competing expert testimony, the judge is choosing between the evidence of two experts; whereas in public law cases the judge is choosing between the views of an expert government body and that of a non-expert litigant. In the former situation, it is justified for the judge to reject one expert view, as he can choose to rely on another expert view. In contrast, in public law cases, if the judge rejects the government's expert view, he would have to rely on the litigant's nonexpert view. In the latter situation, it would hardly be justified for the court to reject the government's expert view unless there are strong grounds for doing so. My reply is, the analogy is applicable in the situation under discussion, in which the government and the litigant's first-order arguments are equally strong, or the court is uncertain which side's arguments are stronger. These are situations where the government is unable to demonstrate its relative expertise through first-order reasons. My argument is precisely that in these situations, courts ought not automatically assume that the public body possesses relative expertise, and may only defer if the government can prove that this is the case.

${ }^{64}$ Poole argues that courts must try to gain access to as much information as possible. Poole, above $\mathrm{n} 5$, at 254 .

${ }^{65}$ Eg Hunt, above n 2, pp 345-347; Kavanagh, above n 18, at 201-203; King, above n 22 at 421, 417-418; Young, above n 2 at 566; Jowell, above n 3; RA Edwards, 'Judicial Deference under the Human Rights Act' (2002) 65(6) MLR 859 at 863-864.
} 
superior institutional competence in wholesale subject areas may prove to be wrong in context. If courts accept claims of general expertise and useful secret information based on mere presumptions or assertions without considering whether these claims are supported by experience, they would be exercising a leap of faith - trusting in something without asking for proof that it is trustworthy. Courts exercising such a leap are irrational and abdicate their responsibility to enforce their best judgment of rights.

Not all past incidents should attract equal weight in the court's assessment of reliability. The weight of the past record would depend on the degree of resemblance the past judgment bears to the present judgment, the recentness of the past incident, and how particularised the incident is.

\section{(c) Establishing second-order reasons: flawed approaches}

Neglect of the above requirements of rationality, fairness and open justice has led at least two prevalent accounts of deference to have supported deference in situations where it is unjustified. King's account suggests that the government's institutional capacity can be presumed and hence need not be openly established. This is shown by his argument that judicial uncertainty and fallibility in and of itself calls for deference. ${ }^{66}$ In situations of uncertainty, one would only rationally defer to another if there are grounds to believe that the latter is more likely to be correct on the question. This is admitted by King, whose 'institutional approach to restraint' focuses on the relative strengths and weaknesses of courts in solving problems. ${ }^{67}$ However, that judges are ignorant, uncertain, or fallible does not automatically entail that the government fares any better on the same question. Let us assume that the government claims that it possesses useful intelligence which shows that the litigant is a terrorist. If the government refused to reveal such intelligence, the court would operate in conditions of uncertainty. Yet this uncertainty is no proof that the government indeed possesses the said intelligence. Whether the court can legitimately consider the government as possessing such information depends on other factors, including, I argue, the government's credibility. King recognises the importance of history in ascertaining whether courts are fallible: '[W]ell-known history' shows that 'courts will get things wrong'. ${ }^{68}$ Yet he critically misses the more important side of the equation in rights adjudication: the government's

\footnotetext{
${ }^{66} \mathrm{King}$, above $\mathrm{n} 22$ at 411-414, 425-426.

${ }^{67}$ Ibid at 410 .

${ }^{68}$ Ibid at 411 .
} 
competence on a particular matter needs to be proved by performance as well. To advocate the slogan 'if in doubt, defer' is to presume that the government possesses superior expertise and knowledge on an issue whenever the courts are in doubt. This breaches rationality, fairness and open justice under the HRA.

Kavanagh's account, on the other hand, emphasises that courts must not be presumed to have inferior competence. ${ }^{69}$ However, her analysis of case law exposes her endorsement of deference even when the basis for deferring is not openly demonstrated to the litigant.

Kavanagh uses the case of Farrakhan to illustrate that it is justified for courts to defer where the case is finely balanced, and there is an information gap between the government and the court. ${ }^{70}$ The Home Secretary refused to allow Farrakhan to enter the UK to address an audience, claiming that non-discloseable intelligence showed that his presence would endanger public order. The Court of Appeal regarded the legal merits as evenly balanced but upon affording a wide margin of appreciation to the Home Secretary due partly to his 'far better' position in reaching an informed judgment, ${ }^{71}$ found that the impugned decision was justified. The court did not openly consider the reliability of the executive's risk assessments and intelligence sources, nor did it expressly probe the purported need to keep intelligence secret from the court. On the face of it, the court simply trusted the government. Kavanagh remarked that the fact that the court in Farrakhan was 'prevented from seeing relevant information' was of 'crucial importance' and justified deference. ${ }^{72}$ Her acceptance that there was indeed relevant secret intelligence, and of the need to defer to the government's 'superior information-gathering powers', shows that for her, deference is warranted even when the basis for trusting that the alleged intelligence exists is not demonstrated to the litigant.

Similarly, Kavanagh cites Gillan to show that deference is justified when the court cannot review relevant evidence. ${ }^{73}$ The House of Lords had to decide whether certain blanket stop and search powers were proportionate in countering terrorism. Lord Scott observed that the court could not question the assessments made by the police and Home Secretary of the seriousness of terrorist threats, because it was prevented from seeing useful intelligence material. ${ }^{74}$ The court did not openly consider the credibility of the organs involved in claiming possession of useful information that could not be disclosed. Kavanagh's defence of

\footnotetext{
${ }^{69}$ Kavanagh, above n 2, at 226; above n 18, at 175, 182, 219.

${ }^{70}$ Kavanagh, above n 2, at 234-235; The Queen on the Application of Louis Farrakhan v Secretary of State for the Home Department [2002] EWCA Civ 606 ('Farrakhan').

${ }^{71}$ Farrakhan at [73].

${ }^{72}$ Kavanagh, above $\mathrm{n} 2$, at 234-235, emphasis added.

${ }^{73}$ Kavanagh, above n 18, pp 214-215; R (Gillan) v Metropolitan Police Commissioner [2006] 2 AC 307.

${ }^{74}$ Gillan, ibid, at [62].
} 
the court's deferential approach shows that for her, courts can legitimately defer without expressly explaining the basis for believing that the said intelligence exists.

Belmarsh was used by Kavanagh to demonstrate the need for deference when the court is uncertain and the government possesses superior expertise and intelligence-gathering powers in making national security decisions. ${ }^{75}$ As explained in section 1 above, in adjudicating whether there was a public emergency threatening the life of a nation, the majority deferred on second-order grounds of official expertise in making national security judgments. The majority also deferred on the ground that the executive was able to consider material that the Lords were not invited to see. ${ }^{76}$ When seeking to rely on such 'expertise' and secret information, the majority (with the exception of Lord Scott who noted, but ultimately dismissed without justification the significance of, the 'faulty intelligence assessments' regarding Iraq $^{77}$ ) seemed to have presumed a link between the executive's possession of certain institutional features (eg staff experienced in making risk assessments) and its ability to make correct judgments. It did not explicitly inspect whether this link was confirmed by recent experience. Nor did the majority expressly consider whether the government had previously been credible in claiming that it had useful secret intelligence material. Apparently, it simply took the government's word (that it possessed useful intelligence in this case) for it. Kavanagh's citing of the court's judgment on this issue to demonstrate the need for deference in light of relevant secret intelligence and official expertise in judging anticipatory and life-and-death national security questions, ${ }^{78}$ shows that for her, courts can grant the existence of institutional grounds for deference without expressly vetting the evidence supporting these grounds.

The trilogy of cases discussed concerns the credibility of the government's intelligence sources and assessments on national security. What the positive evidence was that enabled the courts and Kavanagh to establish such credibility in those cases - including overcoming negative evidence of such credibility ${ }^{79}$ - remained in the dark. There was no opportunity for the litigants in those cases to challenge the evidence and reasoning behind the generous dose of deference that crucially led to their defeat on the issues concerned. Kavanagh's sanction of deference in these cases violates judicial impartiality and open justice.

\footnotetext{
${ }^{75}$ Kavanagh, above n 18, pp 212-213, 215-218.

${ }^{76}$ Belmarsh at $[27,94,117,226]$.

${ }^{77}$ Belmarsh at [154]; Poole criticised the court for 'sidestepping' risks, above n 5, at 250.

${ }^{78}$ Kavanagh, above n 18, pp 212-218.

${ }^{79}$ See below n 95-100.
} 


\section{REPLY TO POTENTIAL OBJECTIONS}

\section{(a) Desirability}

My track record proposal may be objected on the basis that it will unduly extend the litigation process and impose a heavy burden on the government. My reply is three-fold. First, we must put things in perspective. I am not saying that track records must be proved and examined in all HRA cases. The government need only establish its past reliability if it seeks to rely on secret information or expertise that cannot generate persuasive first-order reasons, and courts only need to examine such records when their balance of first-order reasons is even or unclear. Cases that meet these conditions, thus attracting the extra hurdle of track records, are likely to be few. ${ }^{80}$

Secondly, the government can avoid taking on the burden of proving reliability by not relying on second-order institutional grounds for deference. One benefit of my track record proposal is that it will provide incentives for the government to try, from the outset, to limit the breadth of non-disclosed information and to proffer reasons applicable to the case. If the government does not want to prove second-order reasons, it will try to perfect its first-order reasons. Either way, transparent and fair adjudication is enhanced.

Thirdly, it is possible to devise rules to make the process of examining credibility manageable. My proposal envisages that rules governing what types of evidence relating to past performance are admissible and how such evidence can be used can be developed by courts and through legislation over time. By way of suggestion, the following procedure can be adopted:

1. First, the government is to adduce positive evidence to show that the institution which it is asking the court to defer to had previously made correct judgments in the type of issues concerned, and/or that its sources of information were reliable in the past.

2. The litigant then has an evidential burden to expose negative records of the government body's credibility, and point out the institutional problems that these blunders expose. If the litigant is unable to point to any negative track record, then the government's credibility can be taken to have been established by step 1 .

\footnotetext{
${ }^{80}$ This is especially so with the introduction of closed-material procedures in certain contexts, under which evidence can be revealed to the court in confidence. Above $\mathrm{n} 10$.
} 
3. If the litigant can discharge its evidential burden, the government must then try to show that the asserted institutional problems exposed by past mistakes have been solved or are not applicable in the present case. The government may also give evidence to show that the alleged problems have been misidentified. Ultimately it is for the court to decide whether on balance the government has sufficiently overcome the alleged negative record.

Apart from placing an evidential burden on the litigant (step 2 above), two other procedural rules may also help simplify the process of assessing track records. One is to admit track records for up to a certain period of time only, for instance, up to ten years before the litigation. Another is to introduce a rebuttable presumption. As positive judicial assessments of a government body's expertise in a certain type of issues accumulate over time, a rebuttable presumption of the requisite competence for that type of questions may be developed, and the government need not go through step 1 all over again when that kind of questions arises. The presumption is rebutted if the litigant is able to raise contrary evidence under step 2.

\section{(b) Feasibility}

My proposal may be objected on the basis that it is not feasible. First, in national security contexts - situations where second-order grounds for deference will most likely be raised - it is inherently most difficult for the government to adduce sufficient evidence for the court to assess past reliability, because much of such evidence cannot be released for public security reasons. It is unlikely that track records can be established in these contexts. Secondly, even if courts are given enough information to assess past performance, they are not capable of making the assessment in relation to government bodies. Such an assessment is often complex, involving evaluation of the history of a large institution (eg the Ministry of Defence), which is reliant on information gathered by another large institution (eg the Security Service).

The first argument may be true, but even if it is, it does not weaken my case. All my theory aims to do is to explicate the condition for legitimate deference on second-order institutional grounds, namely, that such grounds must be backed by evidence. It does not follow from my theory that this condition will be met in all cases. In fact it is envisaged that such a high threshold for legitimate deference will not be met in some cases. If in a national 
security case the government is unable or unwilling to adduce enough evidence to prove that it is reliable, then according to my theory, the threshold for legitimate deference is not crossed and the court should simply not defer. If in reality the government is rarely able or willing to prove past credibility in national security cases, then according to my theory, this simply goes to show that deference on second-order grounds is rarely warranted in these contexts of secrecy. This conclusion may be surprising given that I started off defending deference on second-order grounds at a philosophical level, but it does not weaken the value of my thesis: that it explicates when deference on second-order grounds is called for, hence explaining why deference is or is not legitimate in specific circumstances.

Once we reflect on the imperatives of rational, open and fair adjudication that underlay my theory, it will not come as a surprise that deference on second-order grounds is warranted exceptionally in the murky world of national security. Intelligence agencies and riskassessing bodies work in conditions of relative secrecy. The public and courts hear much about these institutions' failures, but know little about their quiet successes. Deferring to bold claims of general expertise and useful secret intelligence in these circumstances would amount to exercising a giant leap of faith - trusting that these bodies are reliable when there is abundant (if not, only) evidence to the contrary. Such a leap blatantly violates the spirit of rights adjudication. Asking the government to earn deference by showing credibility in national security contexts may sound harsh, but is entirely justified. The government is not absolved from the responsibility to earn trust from courts merely because national security is involved. ${ }^{81}$ If it demands trust, it must proffer evidence to show that it is trustworthy. The bottomline is, courts should never grant unconditional trust in judicial review.

Although I acknowledge that it may be difficult to prove credibility in national security cases, I would not overestimate such difficulty. We currently believe that establishing track records in national security cases is hard, because we have no idea how the exercise can be conducted, in particular, what kinds of information can be adduced for such purposes. We have never seen track records being established. My proposal will urge intelligence and riskassessing institutions to try their best to prove credibility, by limiting non-discloseable information to what is truly absolutely necessary. Experience shows that the government will do better with pressure. Partly in response to criticisms from the Intelligence and Security Committee ('ISC') in $2009{ }^{82}$ the government has compiled and released details of those

\footnotetext{
${ }^{81}$ A Tomkins, 'National security and the role of the court: a changed landscape?' (2010) 126 LQR 543 , at 567.

${ }^{82}$ Intelligence and Security Committee, 'Could 7/7 have been prevented? Review of the Intelligence on the London Terrorist Attacks on 7 July 2005', presented to Parliament in May 2009, paras 284-285.
} 
convicted for terrorism offences for the past ten years - data that was previously unavailable. ${ }^{83}$ This is a 'simple, yet essential' piece of evidence that can demonstrate how well our intelligence institutions are functioning, ${ }^{84}$ and the ISC contributed to prompting its release. Judicial interrogation may be able to compel the government to disclose useful departments of information that had never been within our cognizance. Proving past reliability in national security cases may seem arduous today, but may turn out to be less difficult than we thought, as the government engages more frequently with the exercise. Just decades ago it was considered unworkable even for courts to challenge judgments made in the name of national security. Now no one would doubt that this judicial exercise is feasible. 'Peering through the glass darkly' may not be as difficult as it seems, ${ }^{85}$ because the glass may turn out to be brighter. My proposal is another step to making what will remain as the most sensitive part of our democracy more accountable.

The second objection is false. Courts are fully capable of assessing the credibility of government bodies. In fact, some judges have already been doing so. In Belmarsh, Lord Hoffmann (dissenting judge on the first issue) and Lord Scott referred expressly to the Iraq failure when evaluating whether to trust the executive's judgment on the public emergency question (although neither judge explained why they were willing to grant the Home Secretary the 'benefit of the doubt' notwithstanding the problems exposed by the Iraq saga). ${ }^{86}$ The increasingly activist attitude of courts in national security cases ${ }^{87}$ is also suggestive. One reason behind this attitude might be the government's recent intelligence failures and misjudgements ${ }^{88}$ - wake-up calls that show that the government can go wrong in this area. There are thus signs to show that serious blunders such as Iraq have prompted some judges to begin to consider, albeit not always in a systematic and explicit fashion, the UK government's track records, questioning orthodox presumptions about official competence; and this article is simply calling for the rationalisation and open articulation of an existing thought process.

\footnotetext{
${ }^{83}$ In 2009, the ISC requested statistics from 2004 onwards but the government said detailed convictions data was only available from 2007. Detailed statistics are now available at the Home Office's website: http://www.homeoffice.gov.uk/science-research/research-statistics/; notable terrorist convictions since 2001 are summarised on the Security Service's website: https://www.mi5.gov.uk/output/terrorist-plots-in-the-uk.html. ${ }^{84}$ Above n 82, paras 289-290.

${ }^{85}$ Poole analogises courts' probing of national security claims to them 'peering through the glass darkly'. Poole, above $\mathrm{n} 5$, at 258 .

${ }^{86}$ Belmarsh, at $[94,96,154]$.

${ }^{87}$ See cases in n 90, 95, 97; Al Rawi v Security Service [2010] EWCA Civ 482; AF (No.3) [2009] UKHL 28; The Queen of the Application of Naik $v$ Secretary of State for the Home Department [2011] EWCA Civ 1546. See De Londras, above n 60, pp 230-279.

${ }^{88}$ Below n 95-100.
} 
Evaluation of the past credibility of institutions has consistently been a part of judicial reasoning. Judges often conduct a qualitative balancing exercise involving positive and negative evidence of reliability. Courts have assessed the past achievements and credibility of expert witnesses and accordingly adjusted the weight of their evidence. ${ }^{89}$ Also, not long ago the court in $A S \& D D$ (Libya) assessed the credibility of the late Gaddafi, and in light of his bad track record in unjustly convicting the 'Bulgarian medics', decided that his assurances to the UK government should not be trusted this time. ${ }^{90}$ These cases demonstrate that courts are equipped to consider and are familiar with evaluating an institution's historical success.

Of course, it may be simpler to evaluate the past record of an individual witness than to evaluate that of a large institution which is reliant on intelligence provided by another large institution. However, there is no reason to believe that courts are unable to conduct the balancing exercise in relation to the latter institutions. The key for courts in assessing the track records of government bodies is to first identify which institution(s) the court is being asked to defer to, and for what judgments. The government/court can then demonstrate/ascertain the reliability of the institution(s) in question using the following sources. The weight of these sources would depend on their recentness, comprehensiveness and independence:

1. Reports issued by or records kept by the institution itself;

2. Reports or statements of evaluation issued by the institution's monitoring organs, such as courts or parliamentary committees;

3. Public inquiries conducted into the work of the institution.

\section{(c) Illustration}

In the following, I will use an example to illustrate how my proposals can be implemented. The example is adapted from the facts of Belmarsh, a case concerning national security - a context that raises most pertinent issues about feasibility. The aim of this section is to illustrate the approach which courts and government bodies can adopt in assessing and demonstrating past performance. The aim is not to show that track records can definitely be established in the given case. For instance, I will highlight the kinds of positive evidence that the government may adduce to demonstrate its credibility, but whether credibility can be

\footnotetext{
${ }^{89}$ Eg Re AB (child abuse: expert witnesses) [1994] EWHC Fam 5, where the court refused to trust an expert witness since his credibility was criticised in previous cases.

${ }^{90} A S \& D D($ Libya $) v$ Secretary of State for the Home Department [2008] EWCA Civ 289 at [72-73].
} 
successfully established in practice will depend on whether the government is willing and able to proffer the suggested evidence. If the government is unwilling or unable to do so, my theory counsels courts not to defer in the case under discussion.

Assume that the Home Secretary argues before the court that there is a "public emergency threatening the life of the nation' that justifies indefinite detention of non-national terrorist suspects. The Home Secretary cites September $11^{\text {th }}$ and the London bombings to support his claim that the said level of emergency exists, but argues that further intelligence gathered from the Security Service and Secret Intelligence Service which supports the claim cannot be revealed to the court, and that in any case, the court must defer to him, who possesses general expertise in making national security risk assessments. The judge weighs these arguments against the litigant's. If the court is unsure which way the argument should go, my proposal would become relevant.

Applying my theory, before the court can allow the government's bold claims of useful secret information and general expertise to add weight to its case, the court must probe the evidential basis of such claims. The court needs to interrogate the Home Secretary on why the intelligence cannot be disclosed and compel him to reveal as much evidence as possible. Having identified the institutions that it is being asked to defer to (ie the Home Secretary, Security Service and Secret Intelligence Service), the court should assess, inter alia, whether the intelligence agencies' sources of intelligence had been reliable, and whether the Home Secretary had previously made accurate and honest risk assessments based on that information.

If at this stage, the government refuses to produce any evidence to prove such record of reliability, then the question of second-order deference ends here: the court should simply not grant the said assertions of institutional competence. Yet if the government is ready to try to establish such credibility, here are some suggestions on the kinds of affirmative evidence it can seek to adduce. As contended by one of the monitoring organs over the intelligence agencies - the ISC, data on conviction of terrorists who were arrested on the basis of evidence collected by the intelligence agencies demonstrates how well these agencies are functioning, how adequate their strategies are and what changes have to be made. ${ }^{91}$ It is thus an objective indicator of whether our intelligence sources are generally reliable, and is relevant to the court in evaluating the reliability of the government's risk assessments, regardless of whether the case in question is concerned with the criminal justice system. Of

\footnotetext{
${ }^{91}$ Above n 82-84.
} 
course, these figures show just a small part of the capabilities of the intelligence agencies, because the government often has to act before it has secured enough evidence to support criminal charges. Yet they are an important indicator of the reliability of intelligence sources which the government can conveniently reveal.

The Home Secretary may also try to produce other evidence of past intelligence successes and accurate risk assessments. For example, he may seek to provide particulars of intelligence successes that had previously been documented in the public domain, including the recent revelation of Iran's secret nuclear site at Qom; ${ }^{92}$ the interception of two explosive devices concealed in air freight in 2010; ${ }^{93}$ and the disruption of an Al Qaeda cell in North West England in 2009. ${ }^{94}$

Not all of the above evidence of 'success' will attract equal weight in the court's appraisal of the government's ability to make risk assessments. As explained in section 3(b), the more resemblance the past judgment bears to the present judgment - that of assessing whether there is a requisite level of public emergency - the more weight it should attract. The more particularised and recent the 'success', the more weight it should attract. What the conviction statistics and examples of intelligence success in the public domain indicate is, the government may be able to adduce and particularise at least some evidence to show why its intelligence and risk assessments are worth relying on in specific cases.

After the government has demonstrated positive evidence, the litigant bears the burden of exposing the negative track records of the Home Secretary and intelligence agencies, and most importantly, to highlight the institutional problems that they uncovered. The litigant may refer to recent criticisms made by courts against the good faith and competence of Security Service officials, ${ }^{95}$ the reliability of the Home Secretary's risk assessments ${ }^{96}$ and the Home Secretary's competence in making national security judgments. ${ }^{97}$ Yet the most compelling evidence that the litigant may raise would be the findings of public inquiries over major intelligence failures such as the Iraq war in 2003. Public inquiries are a particularly valuable means of ascertaining the credibility of intelligence and risk-assessing institutions,

\footnotetext{
92 'Justice and Security Green Paper', presented to Parliament by the Secretary of State for Justice, October 2011, available at http://www.official-documents.gov.uk/document/cm81/8194/8194.pdf, p 4.

93 Ibid.

94 'The Threat to National Security', address by the Director General of the Security Service, Jonathan Evans, at the Worshipful Company of Security Professionals, 16 September 2010, para 11, available at https://www.mi5.gov.uk.

${ }_{95}$ Binyam Mohamed $v$ Secretary of State for Foreign and Commonwealth Affairs [2010] EWCA Civ 65 at [168]. ${ }^{96} A S \& D D$ (Libya), above n 90 at [73].

${ }^{97}$ Lord Alton of Liverpool $v$ Secretary of State for the Home Department (Nov 30, 2007). See also $R$ (on the application of Al-Sweady) v Secretary of State for Defence, [2009] EWHC 1687 (Admin) at [23].
} 
because they uncover much non-disclosed information, and are generally conducted relatively independently. Tomkins argued in the context of the Scott Inquiry that important lessons can be learnt from the report: 'Before Scott we might have suspected that Britain's security and secret intelligence services were not being used as efficiently as they might be, but again, we could not tell for sure. Now we can, and now that Scott has filled in some of the gaps, we are for the first time in a position to know a little more about what we can actually do about it. ${ }^{98}$ Public inquiries into the Iraq fiasco in 2003 confirmed suspicions of institutional problems in our intelligence machinery, some of which were subsequently openly admitted by the then Prime Minister. ${ }^{99}$ These problems include: ${ }^{100}$ lengthy reporting chains, under-resourced validation process, compartmentalisation of intelligence, overreaction to past under-estimates; and the executive's omission of important information in the dossier, calling into question the executive's integrity. Academics, journalists and the general public have taken these problems into account in evaluating our intelligence agencies and politicians. Naturally, the courts, being the major monitoring organ of these institutions, should not turn a blind eye to these glaring records when deciding whether to grant the government the benefit of the doubt where human rights of the litigant are at stake.

Once the litigant has demonstrated negative track records, the onus shifts to the Home Secretary to reaffirm the reliability of his risk assessments and intelligence sources. He can do so by showing that the institutional problems raised by the litigant have been solved, are not relevant to the case in question or have been misidentified. For instance, the government may wish to give particulars of how relevant recommendations in the Butler report have been implemented, ${ }^{101}$ and how recent reforms to the intelligence machinery (such as the establishment of the National Security Council) ${ }^{102}$ have alleviated problems of the court's concern in the present case. My conjecture is this will be an uphill battle for the government, given the recentness of the negative incidents, and concerns expressed by the ISC that certain

\footnotetext{
${ }_{98}$ A Tomkins, The Constitution After Scott (Oxford: Clarendon Press, 1998) p 1.

99 'The Butler Report: Britain's Iraq intelligence falls short' (CBC News, 28 June 2004), available at http://www.cbc.ca/news/background/Iraq/butler_report.html.

${ }^{100}$ Numerous inquiries have been held on pre-Iraq war intelligence. Eg the Butler Review (14 July 2004), available at http://www.archive2.official-documents.co.uk/document/deps/hc/hc898/898.pdf, see esp paras 108117; the Chilcott Inquiry: http://www.iraqinquiry.org.uk/.

${ }^{101}$ The Chief of the Security Intelligence Service was 'confident' that the Butler recommendations have been implemented: 'Britain's Secret Frontline', address by Sir John Sawers, $28^{\text {th }}$ October 2010, available at https://www.sis.gov.uk/. We will have a better picture of whether they truly are once the Chilcott Inquiry delivers its findings.

102 This body comprises top officials from departments responsible for national security. It was established to coordinate efforts. See: http://www.cabinetoffice.gov.uk/content/national-security-council/.
} 
Butler recommendations have not been implemented. ${ }^{103}$ It is in the end for the court to qualitatively evaluate whether it is safe to trust that the Home Secretary indeed possesses the said intelligence and has accurately assessed the emergency level that UK is facing, all things considered.

\section{REVISITING THE DEBATE}

Two curious observations on the current debate culminate from the above discussion. Firstly, while deference on second-order institutional grounds is theoretically warranted in situations of judicial uncertainty, in reality - at least insofar as government institutions in contemporary UK are concerned - it will likely only be justified exceptionally in national security contexts, since it will likely be difficult to establish second-order grounds in these cases. This is contrary to Kavanagh's stance that deference is most warranted in national security contexts. So while Allan's starting premise - that courts should never defer on second-order grounds is theoretically indefensible, the practical implications of his theory in this area are probably closer to the incidence of deference warranted, as compared to that of Kavanagh's theory.

Secondly, at least King and Kavanagh's accounts of deference fall prey to Allan's criticisms against deference theories, being that they encourage abdication of judicial responsibility and impartiality and hinder the growth of a culture of justification (corresponding to the requirements of rationality, judicial fairness and open justice). As demonstrated in section 3(c), King and Kavanagh's accounts breach all or some of these requirements because they grant second-order grounds of institutional capacity leniently. So Allan's conclusion on the problems of prevalent accounts of due deference is ultimately valid at least against two accounts, not because, as his premise states, deference for second-order reasons itself leads to such problems, but because these accounts omit the need for courts to openly consider various factors in establishing such reasons.

That certain elements of Allan's case remain undamaged despite its flawed starting premise should not be surprising, given that an assumption underlying Allan's theory is valid, namely, any discussion of deference must take into account the requirements of rational, impartial, and transparent adjudication in a rights-based democracy. This article has sought to answer the two questions posed at the beginning in a way that remains faithful to these imperatives. It has argued that firstly, rationality warrants deference on second-order grounds

${ }^{103}$ ISC, 'Report into the London Terrorist Attacks on 7 July 2005', presented to Parliament in May 2006, p 32. 
of institutional competence in situations of judicial uncertainty. Secondly, the government must prove the existence of such grounds, and the court must openly consider numerous factors including the government's past performance in assessing whether such grounds exist. It is hoped that this article could provide courts with more guidance as to when to defer in HRA cases. At the very least, it is hoped that this article has shown that (1) the debate on deference on the ground of institutional capacity is not yet resolved, and (2) the question of when courts can legitimately trust the government's claims of secret information and general expertise deserves more attention. 